\title{
Epipelon dynamics in a shallow lake through a turbid-and a clear- water regime
}

\author{
María G. CANO,$^{*}$ María A. CASCO,${ }^{1}$ María C. CLAPS ${ }^{2}$ \\ ${ }^{1}$ D.C. Ficología, Facultad de Ciencias Naturales y Museo, Universidad Nacional de La Plata, Consejo Nacional de Investigaciones \\ Científicas y Técnicas, Avenida 122 y 60, 1900 La Plata, Buenos Aires; ${ }^{2}$ Instituto de Limnología R.A. Ringuelet, Facultad de Cien- \\ cias Naturales y Museo, Universidad Nacional de La Plata, Consejo Nacional de Investigaciones Científicas y Técnicas, CC 712, \\ 1900 La Plata, Buenos Aires, Argentina \\ *Corresponding author: mgcano@fcnym.unlp.edu.ar
}

\begin{abstract}
In Pampean lakes, very little information is available on epipelon structure and dynamics or the effect of environmental variables on those parameters. We anticipate that light may have the greatest influence on this community and that the nutrient concentration and substrate instability may exert secondary effects. Our objective was to analyze variations in descriptive parameters and in the algal species composition of the epipelon in the Pampean Lake Lacombe over space and time to establish the most influential environmental forces (light climate, wave action, nutrients). Sediment was collected from the benthos with a 3.5-cm-diameter corer in a year-round sampling every month at four sites in the lake that differed from each other in depth, distance from the shore, and the presence of emergent and submerged macrophytes. Although Lacombe is a shallow lake, differences occurred in community descriptive variables and in the epipelon composition (especially diatoms) over space and time. In particular, differences between the site nearest to the shore and the rest of the sites were found with respect to environmental variables (sediment-particle size, total phosphorus, organic matter content, light climate), epipelon descriptive parameters (abundance, chlorophyll a and Margalef's index) and epipelon composition (especially specific biovolume and diatom-size classes). The epipelon also reflected, though slightly, the change from the turbid-to clear-water states in the lake. Sediment erosion or deposition was evidenced by differences in the sediment-particle composition and the predominant particle-size classes at each site. Statistical analyses indicated linear correlations between the epipelon parameters and variables related to the light climate in the water column. Conductivity and sediment total phosphorus and density were also correlated, but to a lesser extent, with epipelon composition. The epipelon variations in Lacombe Lake would exemplify the reference communities developed during clear or turbid regimes in Pampean shallow lakes. We found evidence for the influence of light climate and wave action (through instability of the substrate) on this community, but the effect of nutrients was negligible. We emphasize that the close relationships maintained by the epipelon with other communities such as the phytoplankton and the epiphyton may superimpose the patterns of variation to those communities onto the epipelon dynamics.
\end{abstract}

Key words: Epipelon; community variations; Pampean seepage lake; Argentina; shallow lake regimes.

Received: September 2015. Accepted: February 2016.

\section{INTRODUCTION}

In shallow lakes where organic sediments accumulate within the photic zone, the benthic algae potentially constitute a sizeable component of the entire lake's primary production (Vadeboncoeur et al., 2001; Cano et al., 2008). Epipelic algal assemblages may support benthic (Strayer and Likens, 1986) and pelagic foodwebs (Vadeboncoeur et al., 2002; Rautio and Vincent, 2006) and may also participate in many chemical and physical processes that determine the dynamics of the ecosystem. Processes in which the epipelon is known to play a key role are oxygenation, an increase in $\mathrm{pH}$, and the storage of nutrients and certain metals (Goldsborough and Robinson, 1996), as well as a regulation of the outflow of phosphorus and nitrogen from the sediment mineralization zone (Jansson, 1980; Hansson, 1988; Dodds, 2003). This community can furthermore contribute to the ecosystem's engineering since the members provide stability to the sediments and as a consequence re- duce the resuspension rate (Sand-Jensen and Borum, 1991; Stevenson, 1996; Poulíčková et al., 2008). Light interception by macrophytes, metaphyton, and/or plankton has been cited as a major force affecting the light climate for this community in lentic habitats (Hansson, 1988; Goldsborough and Robinson, 1996; Lassen et al., 1997; Bourne, 2000; Flödder et al., 2006) and especially in eutrophic lakes (Libouriussen and Jeppesen, 2006). Another influence is the frequent disturbance through water movements (Lassen et al., 1997) - e.g., scouring - or animal burrowing in the often loose sediment habitat, which activity may leave the algae buried under several millimeters of sediments, thus without light and in an anoxic ambience (Moss, 1977). In contrast to the circumstance with planktic algae, nutrient availability may not be a problem for the epipelic organisms, even in oligotrophic lakes, because of the close and direct relationship between this community and the sediments (Sand-Jensen and Borum, 1991). 
In Pampean lakes the reference epipelon composition is largely unknown. Very little information about epipelic algae or the influence they receive from environmental variables such as resuspension has been gathered. Such comparative studies have rather been undertaken only within the context of other communities like the phytoplankton (Izaguirre et al., 1994; Allende et al., 2009) as is the instance in most lakes (Cantonati and Lowe, 2014). The gap of information on the assemblages that develop in these wetlands has hindered even the most minimal conceptualization about the processes that take place in these ecosystems (Quirós et al., 2002). Environments such as Lacombe Lake constitute a fundamental component in the Pampean landscape whose study is of limnological interest because they are located within the transitional area between the Subtropical and Patagonic biogeographical regions and constitute a sizeable reservoir of biodiversity (Gómez and Toresani, 1999).

Lacombe (a typical Pampean seepage lake) presents stable turbid- and clear-water regimes that may last for months to a year (Cano et al., 2008; 2012; 2013; Casco et al., 2009; Allende et al., 2009). This lake was chosen for study because of its relatively marginal degree of environmental degradation, with low-density cattle breeding and sport fishing being the only human activities recorded during the study period and those anthropic influences having no recognizable ecologic impact on that body of water (Cano et al., 2012). Pampean lakes are naturally eutrophic with rather variable water total phosphorus (TP) concentrations: the higher mean values (range: 433-713 $\mathrm{mg} \mathrm{m}^{-3}$ ) occur in turbid lakes and lower levels (135-230 $\mathrm{mg} \mathrm{m}^{-3}$ ) in clear ones. In contrast, in shallow lakes characterized by inorganic turbidity, the TP concentration ranges from 811 to $7912 \mathrm{mg} \mathrm{m}^{-3}$ (Quirós et al., 2002; Allende et al., 2009). The algal assemblages present in Lacombe sediments are composed of representatives of the epipelon sensu lato (Pouličková et al., 2014). We suggest that the epipelon composition of Lacombe Lake may well represent the benthic community that is developed under undisturbed, natural conditions in vegetated Pampean lakes, especially those without inlets and outlets. The description of reference conditions and communities is a critical issue for judging the ecologic status of shallow lakes in terms of the degree to which present-day conditions deviate from those otherwise expected in the absence of anthropic influences (Bennion et al., 2014).

Although we have previously analyzed certain aspects of the relationship between the epipelon and plankton communities in Lacombe Lake (Casco et al., 2009) we did not further explore which environmental conditions may have been influential for the epipelon during periods of contrasting turbid- and clear-water regimes. We hypothesize here that epipelon variations over time - and particularly, those community changes that occur as a gra- dient within varying distances from the shore - will be related to the light conditions at the lake bottom. Furthermore, we would predict that the nutrient concentrations and the instability of the benthic substrate constitute secondary transformational drivers. The objective of this work was therefore to analyze the variations in the epipelon descriptive variables and species composition over space and time in an undisturbed Pampean lake to ascertain which of the above mentioned parameters are the most influential.

\section{METHODS}

\section{Study site}

Lacombe Lake (35 $50^{\prime}$ S; $57^{\circ} 53^{\prime}$ W; Fig. 1), mean and maximum depths 1.88 and $2.50 \mathrm{~m}$ and lying over former marine and eolian sediments, has a muddy bottom with a high organic content because of the large amount of emergent and submerged vegetation that may cover most of the lake surface. Permanent stands of the bulrush Schoenoplectus californicus (Mey.) Sojak grow at the center and near the shore. These plants have an active growth during the spring and summer, with the stands becoming denser through stem production during that part of the year (Tur and Rossi, 1976). The submerged macrophytes Stuckenia striata (Ruiz \& Pavon) Holub. and Myriophyllum quitense Kunth develop among the bulrush stands and in places free of the emergent plants. Detail about the region's climate and the lake morphometry were given in Cano et al. (2008, 2012), Casco et al. (2009), and Cano (2009).

Three heavy rainfalls occurred during the study period (from July 2001 through June 2002): in August (191 mm) and October $(219 \mathrm{~mm})$ of 2001 and in March $(515 \mathrm{~mm})$ of 2002. Hydrometric increases of $34.5 \mathrm{~cm}, 15 \mathrm{~cm}$, and $60 \mathrm{~cm}$, respectively, were registered immediately after these precipitations. Two stable states (as defined sensu Scheffer et al., 1993) could be discriminated by Casco et al. (2009): a turbid-water state extending from July through September was characterized by the presence of abundant phytoplankton and the absence of submerged macrophytes. After the heavy rainfalls of October a clearwater state became established as a result of the development of submerged macrophytes and a diminution in phytoplankton biomass. The degree of transparency remained high even after the stands of submerged macrophytes disappeared throughout most of the lake except for the shallower parts after the March rainy interval. By May, these plants had recovered and stabilized the clear water-phase through June, when the study was completed.

\section{Sampling and laboratory techniques}

Sampling was carried out every month at four sampling sites. In preliminary field work, we had recognized that the presence of emergent and submerged macro- 
phytes, the distance from the shoreline and the relative depth were influential variables with respect to the status of algal communities and thus the stations were established under consideration of those conditions (Fig. 1): Station 1 (St. 1) at the center of bulrush stands and $340 \mathrm{~m}$ from the shoreline, had a mean depth of $2.25 \mathrm{~m}$ and a variable abundance of submerged macrophytes; Station 2 (St. 2) at the periphery of the bulrush stands and approximately $160 \mathrm{~m}$ from the shoreline, had a mean depth of $2.28 \mathrm{~m}$, and a variable submerged macrophytes cover; Station 3 (St. 3) at a bulrush-free area and $180 \mathrm{~m}$ from the shoreline, had a mean depth $2.25 \mathrm{~m}$ and abundant submerged macrophytes; Station 4 (St. 4), a second bulrushfree zone and $7 \mathrm{~m}$ from the shoreline, had a mean depth $1.22 \mathrm{~m}$ and dense beds of submerged macrophytes. Duplicate sediment samples were collected at the four sampling points with core samplers of diameter $3.5 \mathrm{~cm}$-and height $2 \mathrm{~cm}$ (Cano et al., 2008).

Physical and chemical parameters (turbidity, dissolved oxygen concentration, $\mathrm{pH}$, conductivity, and temperature) were measured at all sites with a HORIBA U 10 multiparameter. Samples for water chemical-analysis determination were collected at just $10 \mathrm{~cm}$ above the sediments for Stations 1, 2, and 3, the deep sites. At these same sites, samples for phytoplankton-chlorophyll analysis were taken in a five-level vertical profile. Because of the shallowness of Station 4, the data and water samples were collected at a depth of $10 \mathrm{~cm}$ from the surface. The transparency was determined with a Secchi disk at each sampling point. Detailed procedures for the analysis of planktic-chlorophyll and water variables such as polyphenols and nutrients were reported in Casco et al. (2009) and Ardohain et al. (2014). The presence of submerged macrophytes was registered at all sites (Cano et al., 2008; Casco et al., 2009). The percent cover of $S$. striata and $M$. quitense along with the density of the S. californicus stems were recorded within ten $1-\mathrm{m}^{2}$ square parcels of area selected at random at each sampling site and on each

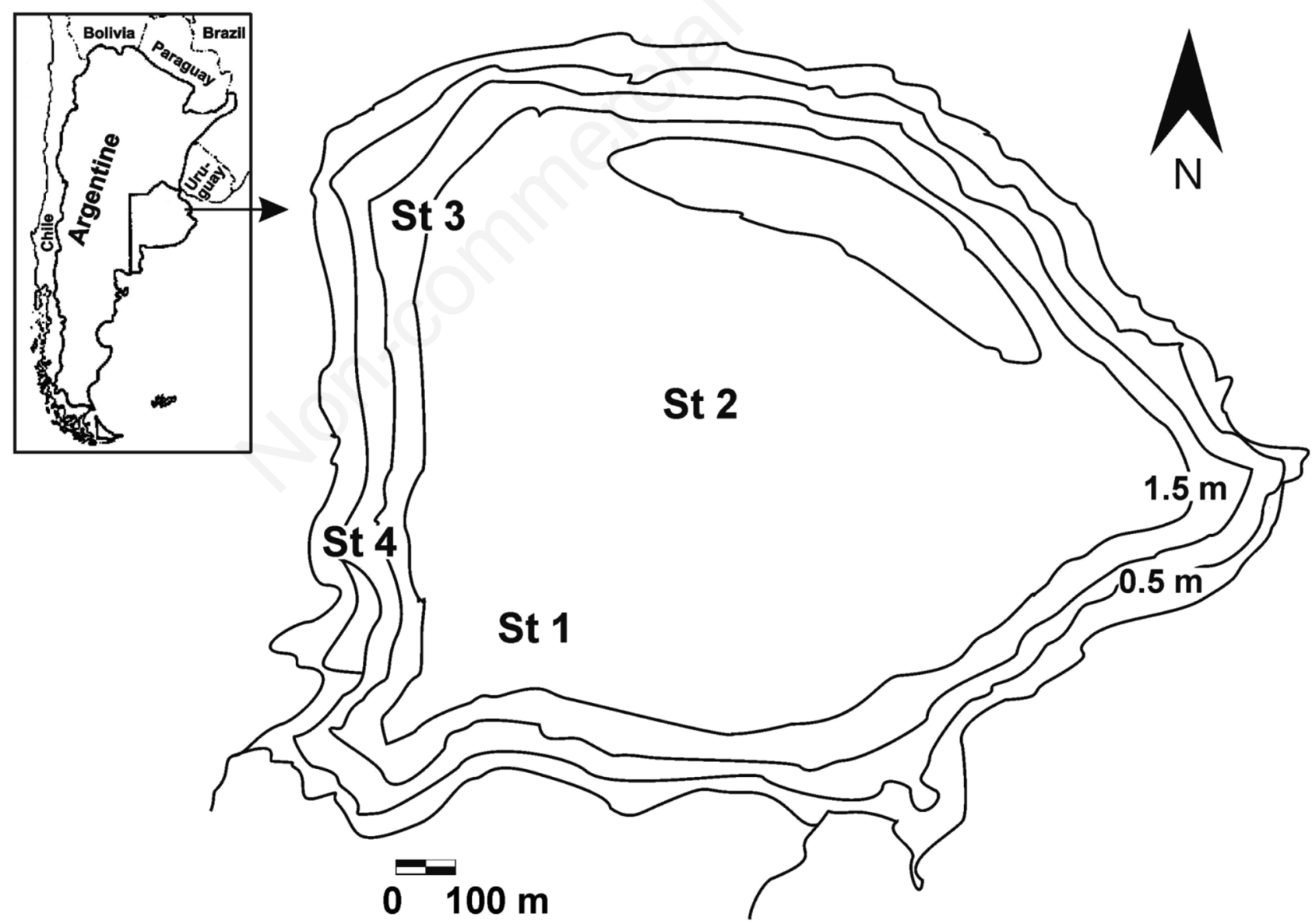

Fig. 1. Site-location bathymetric map of Lacombe Lake. References: St 1. Station 1 (deep water, at periphery of the bulrush stands), St 2. Station 2 (deep water, in the center of bulrush stands, St 3. Station 3 (deep, open water, with or without submerged macrophytes), St 4. Station 4 (shallow, open water, with or without submerged macrophytes). 
sampling occasion. In the laboratory, after conveniently diluted sediment samples were suspended by gentle stirring, two aliquots $(20 \mathrm{~mL}$ ) were separated (suctioning with pipes of $4 \mathrm{~mm}$ of diameter): one for the estimation of TP and particulate organic matter (POM), and another for the analysis of chlorophyll $a$ and phaeopigment concentrations. Detailed procedures for the analyses of the sediment variables were provided in Casco et al. (2009). The remaining material was kept for epipelon analysis.

According to the classification proposed by Pouličková et al. (2014), the algal assemblages present in the Lacombe sediments are composed of representatives of the epipelon (sensu stricto), the endopelon, the epipsammon, the endopsammon, and the meroplankton. Quantification of the epipelon sensu lato was performed on $50 \mu \mathrm{L}$ aliquots taken from the suspended sample and placed on a slide under a $1.8 \times 1.8 \mathrm{~cm}^{2}$ coverslip (Cattaneo, 1983). Smaller organisms and larger ones were counted in random fields at a magnification of $600 x$ or $200 x$, respectively. The minimal area was established for each sample in both magnification categories by the species curve-method (Margalef, 1974; Wilmotte et al., 1988). The quantification proceeded until no more species were found within 20 random fields, which practice in turn made the species-area curve stabilize at near an asymptotic value. Granulometric sediment characterization was also made by light microscopy during epipelon quantification. The pigment concentration and organism density were first normalized to an area by considering the percentage of the total weight of the sample represented by each aliquot withdrawn for the particular analysis, and then that same percent was regarded as equivalent to the fraction of the total area sampled by the core sampler. Algal identification was assessed according to the references cited in Cano et al. (2013) and was updated through the use of the Algaebase Database (Guiry and Guiry, 2015).

Measurements of the specimen sizes to be used for the estimation of biovolume were made in the process of quantification. We considered biovolume as the total volume occupied by an organism: for example, if the organism had a sheath, the latter was included in this calculation. With large size variations in a species, the method of size classification was employed (Rott, 1981). The calculation of average biovolume was done on the basis of the figures and formulas of Hillebrand et al. (1999). The biovolume of the total algae per unit area $\left(\mu \mathrm{m}^{3} \mathrm{~cm}^{-2}\right)$ of each sample was divided by the corresponding total density (ind. $\mathrm{cm}^{-2}$ ) to obtain the average biovolume per individual $\left(\mu \mathrm{m}^{3}\right.$ ind. $\left.^{-1}\right)$ in a given sample. This measurement gives an idea of the size of organisms that compose a community (i.e., if most of the individuals are large or small). Diatoms were likewise sorted in biovolume categories in order to make evident any spatial differences related to size.

\section{Data analysis}

The euphotic depth $\left(\mathrm{Z}_{\mathrm{eu}}\right)$ was determined according to Scheffer (1998) through the use of the light-attenuation coefficient (E) calculated on the basis of the Secchi readings and the average of the five-level-profile of phytoplankton chlorophyll- $a$ concentrations. The physiologic state of algal assemblages was evaluated by Margalef's index [viz (OD430) (OD665) $)^{-1}$, where OD is the optical density at the specified wavelength] and a pigment index expressed as percentage [(chlorophyll $a$ concentration) (chlorophyll $a+$ phaeopigments) ${ }^{-1}$ 100] (Ramírez, 2005).

In the Analyses of Variance (ANOVA) and Pearson's product-moment correlations, the data were previously checked for normality distribution (Kolmogorov-Smirnov tests plus Lilliefors's modification) and transformed if necessary $([\log x+1]$ or square root). When the normality distribution assumption was not met, the nonparametric Kruskal-Wallis ANOVA was performed together with Multiple Comparisons Tests between medians. In nonmetric multidimensional scaling (MDS), an analysis of similarities (ANOSIM) and the multivariate BIO-ENV procedure were carried out with the Primer 5.1 statistical package (Clarke and Warwick, 2001). For both, the MDS test (400 iterations) and the ANOSIM (5000 iterations, the similarity matrix was calculated by means of the Bray Curtis similarity index formula, and the data were fourth root transformed and standardized. In the BIO-ENV test the similarity matrix for species abundance was constructed in a similar way to that of the MDS. The environmental variable similarity matrix was built through the use of the normalized- Euclidian-distance formula and standardized data.

\section{RESULTS}

\section{Benthic environment}

The sediments from Lacombe Lake were light brown and were largely composed of organic particles. The mean POM concentrations were significantly higher at St. 1 and St. 2 (Tab. 1). The organic-matter content was strongly correlated with a higher TP concentration (Pearson-r: 0.87; $\mathrm{P}=0.001)$. At the deep stations the sediments had significantly lower mean densities in comparison to the value at St. 4 (Tab. 1). Sand and dark iron particles were more abundant at the latter site (up to $75 \%$ of the sediment-particle composition). As regards water physical and chemical characteristics, significant differences between the station 4 and the rest of the sampling points could be observed only with respect to the dissolved oxygen values (ANOVA or Kruskal-Wallis tests; Tab. 1).

At St. 1 and St. 2, the epipelon may have experienced unfavorable light conditions until November (Fig. 2). The hydrometric increases coincident with the August precipitations were related to a worsening of light conditions at 
the sediment surface. In contrast, the water-level increases caused by October and March rainfalls were linked to a decrease in the incident light at the bottom. The submerged macrophytes started to grow in spring, after the October heavy rainfalls. The plants began diminishing their cover in February during their fruiting period and survived at St. 3 and St. 4 after the March rainfalls. The distribution of $S$. striata essentially accounted for the total macrophyte coverage on all occasions at the four sites. Myriophyllum quitense developed only at St. 3 and St. 4, reaching a maximum cover of $40 \%$ in January at the latter site (Fig. 2).

\section{Epipelon assemblages}

The epipelon assemblages consisted in a dispersed association of individuals, living both on and between the easily resuspended sediment particles. Most of the 136 taxa encountered were cyanobacteria and diatoms, and to a lesser extent, chlorophytes. The species-richness values were higher at the shallower St. 4 (maximum: 67 species in June) and lower at St. 1 (minimum: 32 species in December) on most of the sampling occasions; lower values were recorded generally during the turbid period. The abundance of the cyanobacteria was fundamentally responsible for the total algal density at the four sampling stations. The chlorophytes and diatoms were less abundant, especially at deep stations. Diatoms made greater contributions to the total density at St.4 from October onwards (Fig. 3). The lowest chlorophyll concentrations were recorded at St. 1 during most of the study period (Fig. 4). At the shallower St. 4, higher figures were recorded from August on reaching the maximum in January $\left(25.2 \mu \mathrm{g}\right.$ chlorophyll $\left.a \mathrm{~cm}^{-2}\right)$. The variations in

Tab. 1. Mean, standard deviation, and range of water and sediment physicochemical variables and of phytoplanktic chlorophyll- $a$ concentration. The data of St.1-St. 3 correspond to a level $10 \mathrm{~cm}$ above the sediments. Data of St. 4 correspond to 10-cm-depth sampling.

\begin{tabular}{|c|c|c|c|c|c|}
\hline \multirow[t]{2}{*}{ Variable } & \multirow[t]{2}{*}{ Unit } & \multicolumn{4}{|c|}{ Sampling stations } \\
\hline & & St. 1 & St. 2 & St. 3 & St. 4 \\
\hline \multicolumn{6}{|l|}{ Water } \\
\hline Temperature & ${ }^{\circ} \mathrm{C}$ & $\begin{array}{c}17.2( \pm 5.1) \\
9.8-23.0\end{array}$ & $\begin{array}{c}17.2( \pm 5.2) \\
9.8-23.3\end{array}$ & $\begin{array}{c}16.8( \pm 4.6) \\
10.3-23.5\end{array}$ & $\begin{array}{c}19.0( \pm 6.3) \\
10.5-30.6\end{array}$ \\
\hline Conductivity & $\mathrm{mS} \mathrm{cm}{ }^{-1}$ & $\begin{array}{c}2390( \pm 843) \\
1320-4160\end{array}$ & $\begin{array}{c}2367( \pm 836) \\
1295-4130\end{array}$ & $\begin{array}{c}2346( \pm 853) \\
1270-4160\end{array}$ & $\begin{array}{c}2192( \pm 799) \\
1260-4120\end{array}$ \\
\hline $\mathrm{pH}$ & & $\begin{array}{c}9.6( \pm 0.4) \\
8.5-10.1\end{array}$ & $\begin{array}{c}9.6( \pm 0.4) \\
8.5-10.3\end{array}$ & $\begin{array}{c}9.7( \pm 0.5) \\
8.3-10.2\end{array}$ & $\begin{array}{c}9.9( \pm 0.6) \\
8.5-10.7\end{array}$ \\
\hline Turbidity & NTU & $\begin{array}{c}47( \pm 36) \\
17-116\end{array}$ & $\begin{array}{c}47( \pm 54) \\
14-180\end{array}$ & $\begin{array}{c}49( \pm 36) \\
12-106\end{array}$ & $\begin{array}{c}42( \pm 32) \\
10-99\end{array}$ \\
\hline Dissolved oxygen & $\mathrm{mg} \mathrm{L}^{-1}$ & $\begin{array}{c}7.2( \pm 2.7)^{\mathrm{a}} \\
1.3-11.5\end{array}$ & $\begin{array}{c}7.9( \pm 2.0)^{\mathrm{a}} \\
3.2-10.5\end{array}$ & $\begin{array}{c}6.7( \pm 2.9)^{\mathrm{a}} \\
0.5-10.6\end{array}$ & $\begin{array}{c}10.1( \pm 1.7)^{\mathrm{b}} \\
7.6-12.4\end{array}$ \\
\hline $\begin{array}{l}\text { Total suspended } \\
\text { solids }\end{array}$ & $\mathrm{mg} \mathrm{L}^{-1}$ & $\begin{array}{c}33.7( \pm 28.7) \\
7.7-85.7\end{array}$ & $\begin{array}{c}33.1( \pm 36.2) \\
6.8-110\end{array}$ & $\begin{array}{c}27.1( \pm 26.6) \\
7.3-88.0\end{array}$ & $\begin{array}{c}20.3( \pm 20.0) \\
4.2-65.7\end{array}$ \\
\hline Polyphenols & $\mathrm{mg} \mathrm{L}^{-1}$ & $\begin{array}{c}4.1( \pm 1.7) \\
2.1-8.7\end{array}$ & $\begin{array}{c}4.6( \pm 2.1) \\
2.4-10.2\end{array}$ & $\begin{array}{c}4.5( \pm 2.0) \\
2.7-9.9\end{array}$ & $\begin{array}{c}6.6( \pm 5.5) \\
2.4-18.8\end{array}$ \\
\hline $\begin{array}{l}\text { Soluble reactive } \\
\text { phosphorus }\end{array}$ & $m g L^{-1}$ & $\begin{array}{c}32.8( \pm 33.1) \\
7.4-128.3\end{array}$ & $\begin{array}{l}27.9(33) \\
7.4-128.6\end{array}$ & $\begin{array}{c}33.9(42.0) \\
7.4-164.3\end{array}$ & $\begin{array}{c}27.2(30.6) \\
7.4-121.4\end{array}$ \\
\hline Reactive silica & $\mathrm{mg} \mathrm{L}^{-1}$ & $\begin{array}{c}5.4( \pm 4.5) \\
0.3-16.5\end{array}$ & $\begin{array}{c}5.0( \pm 3.3) \\
0.3-11.9\end{array}$ & $\begin{array}{c}4.8( \pm 3.6) \\
0.3-11.9\end{array}$ & $\begin{array}{c}6.1( \pm 4.8) \\
0.7-15.0\end{array}$ \\
\hline $\begin{array}{l}\text { Nitrates + } \\
\text { Nitrites }\end{array}$ & $\mathrm{mg} \mathrm{L} \mathrm{L}^{-1}$ & $\begin{array}{c}175( \pm 84.8) \\
49-337\end{array}$ & $\begin{array}{c}187( \pm 132) \\
54-500\end{array}$ & $\begin{array}{c}176( \pm 64) \\
66-263\end{array}$ & $\begin{array}{c}185( \pm 92) \\
59-419\end{array}$ \\
\hline Ammonia & $\mathrm{mg} \mathrm{L}^{-1}$ & $\begin{array}{c}384( \pm 251) \\
71-808\end{array}$ & $\begin{array}{c}410( \pm 206) \\
132-751\end{array}$ & $\begin{array}{c}439( \pm 237) \\
132-937\end{array}$ & $\begin{array}{c}371( \pm 174) \\
71-689\end{array}$ \\
\hline $\begin{array}{l}\text { Phytoplanktic } \\
\text { chlorophyll } a\end{array}$ & $\mathrm{mg} \mathrm{m}^{-3}$ & $\begin{array}{c}39.9( \pm 36.4) \\
1.3-132.7\end{array}$ & $\begin{array}{c}30.6( \pm 18.8) \\
13.4-71.3\end{array}$ & $\begin{array}{c}34.4( \pm 27.3) \\
0.7-100.7\end{array}$ & $\begin{array}{c}25.7( \pm 20.2) \\
3.3-72\end{array}$ \\
\hline \multicolumn{6}{|l|}{ Sediments } \\
\hline Density & $\mathrm{mg} \mathrm{cm}^{-3}$ & $\begin{array}{c}13.7( \pm 4.2)^{\mathrm{a}} \\
7.1-18.2\end{array}$ & $\begin{array}{c}18.9( \pm 5.8)^{\mathrm{a}} \\
12.1-30.3\end{array}$ & $\begin{array}{c}35.8( \pm 11.1)^{\mathrm{b}} \\
21.7-56.3\end{array}$ & $\begin{array}{c}71.1( \pm 36.1)^{\mathrm{c}} \\
20.0-135.2\end{array}$ \\
\hline Total phosphorus & $\begin{array}{l}\mathrm{mg} \mathrm{g}^{-1} \mathrm{dw} \\
\text { sed }\end{array}$ & $\begin{array}{c}557( \pm 62)^{\mathrm{a}} \\
446-642\end{array}$ & $\begin{array}{c}560( \pm 96)^{\mathrm{a}} \\
358-712\end{array}$ & $\begin{array}{c}360( \pm 98)^{\mathrm{b}} \\
225-560\end{array}$ & $\begin{array}{c}258( \pm 80)^{\mathrm{c}} \\
186-420\end{array}$ \\
\hline Particulate organic matter & $\begin{array}{l}\mathrm{mg} \mathrm{g}^{-1} \mathrm{dw} \\
\text { sed }\end{array}$ & $\begin{array}{c}282( \pm 20)^{\mathrm{a}} \\
255-324\end{array}$ & $\begin{array}{c}243( \pm 16)^{\mathrm{ab}} \\
217-274\end{array}$ & $\begin{array}{c}110( \pm 37)^{\mathrm{bc}} \\
55-201\end{array}$ & $\begin{array}{c}60( \pm 29)^{c} \\
28-116\end{array}$ \\
\hline
\end{tabular}

Total number of observations, $n=12$ (for each mean and standard deviation). ${ }^{a-c}$ Different letters indicate significantly different groups at $P<0.05$. 
phaeopigment concentrations were similar at all sites; with a marked increase in spring. This increment reflected the decline in the community's physiologic status, and it produced a decrease in the pigment index from a mean value of $65 \%$ (first three months) to $32 \%$ (for the rest of the study period, excluding the October and November data). The change from a better to a worse physiologic state was almost imperceptible at the deeper sites on the basis of Margalef's index. The average values for the July-September and for December-June periods (i.e., 5.2 and 6.1, respectively) indicated a mature community. At St. 4, these values were lower (i.e., 3.5 and 4.7, respectively) indicating the presence of less mature communities (Fig. 4). The total biovolume at the deeper sites tended to diminish, while the values for St. 4 became more variable. If the biovolumes of Microcystis aeruginosa colonies are included in the calculation, then the average total biovolume varied markedly, especially from December on (Fig. $5 \mathrm{~A}$ ). With the exclusion of the M. aeruginosa variations, the average biovolume-per-individual values were similar throughout the study period, with a diminution occurring in December when the community was constituted by smaller forms (Fig. 5B). Twelve of the species represented $65-85 \%$ of the total density at all stations over the entire study period (Fig. 6). Among these twelve, Planktolyngbya minor, Aphanocapsa holsatica, Tetraedron minimum, Oocystis parva, Cosmarium aff. phaseolus, Navicula veneta, and Pseudostaurosira aff. subsalina were the most
St.1

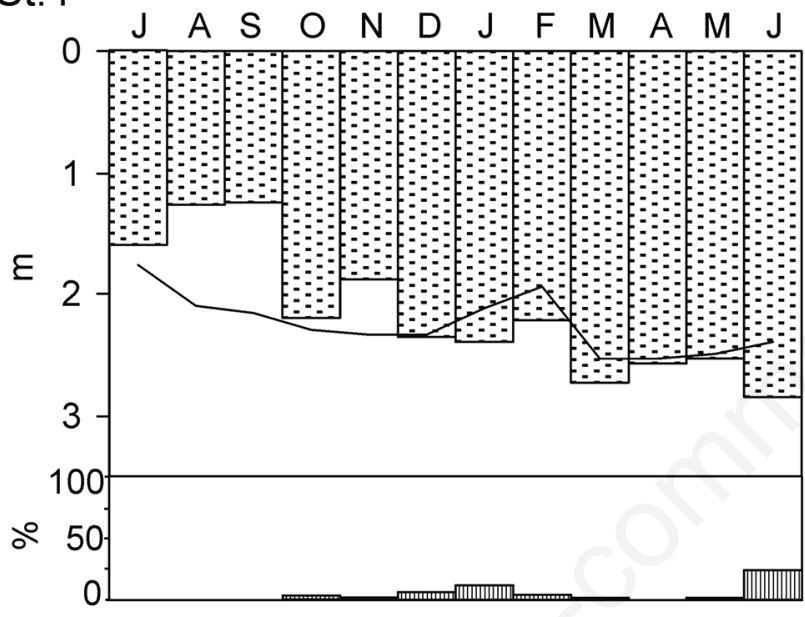

St. 2

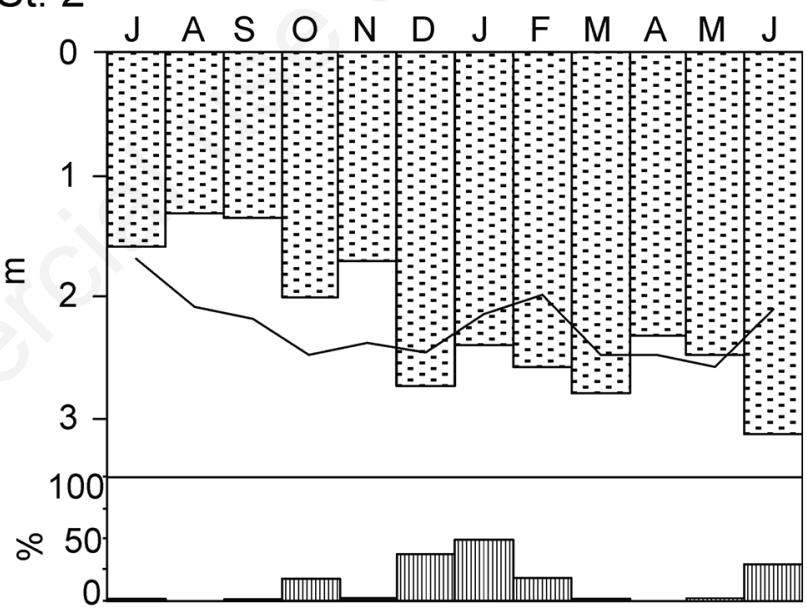

St. 3

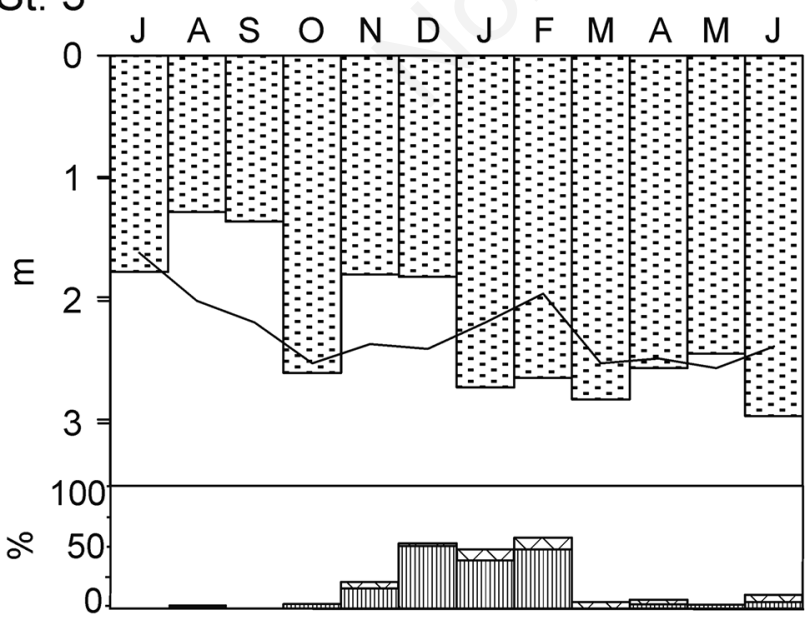

St. 4

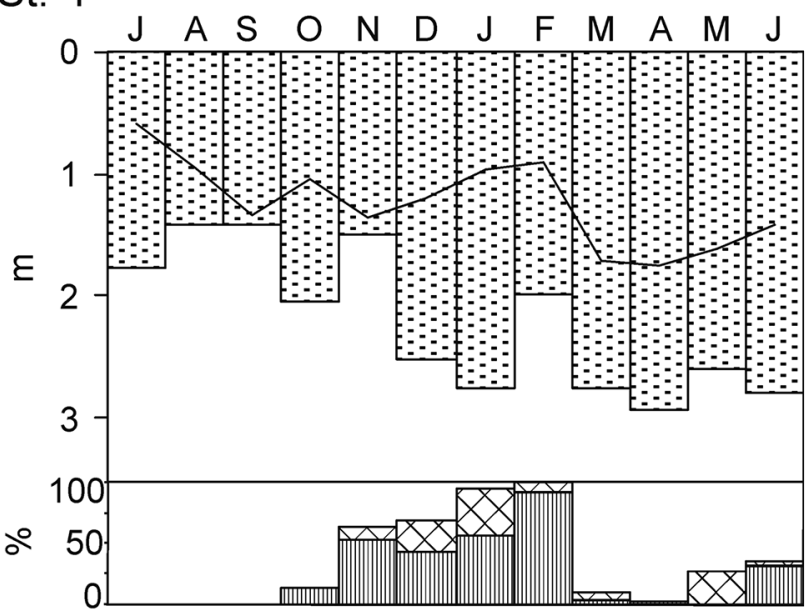

Fig. 2. Euphotic-zone depth and depth at the four sampling stations (both in meters) and percentage of submerged-macrophyte cover. Upper panels: $Z_{\mathrm{eu}}$ (dotted columns) and depth (black line). If $Z_{\mathrm{eu}}$ is greater than the depth, then $1 \%$ or more of the incident light reached the sediment surface. Lower panels: percent coverage of submerged macrophytes: Stuckenia striata (vertically hatched columns); Myriophyllum quitense (obliquely hatched columns). 
abundant. With respect to biovolume per species, 14 taxa contributed each with $10 \%$ or more of the total value each throughout the sampling points and on any date. Among the cyanobacteria, $M$. aeruginosa represented more than $80 \%$ of many of the samples, followed by A. holsatica and Chroococcus dispersus. The chlorophytes contributed with less than $20 \%$ to the total biovolume (particularly Pseudopediastrum boryanum, T. minimum, and $O$. parva). The diatoms manifested differences among the four sites, when separated into four specific average-biovolume size classes. The taxa with biovolumes greater than 100,000 $\mu \mathrm{m}^{3}$ (Campylodiscus clypeus and Surirella striatula) contributed with higher percentages to the diatom total biovolume at St. 1 and St. 2 (Fig. 7). The smaller diatoms as $N$. veneta and Nitzschia amphibia (class 100-999 $\mu \mathrm{m}^{3}$ ) or Halamphora veneta and Rhopalodia gibba (class 1000$9999 \mu^{3}$ ) presented higher contributions at St. 4. Medium-sized diatoms (class 10,000-99,999 $\mu \mathrm{m}^{3}$ ) - e.g., Plagiotropis lepidoptera or Rhopalodia aff. rupestris represented higher percentages at St. 3 (Fig. 7).

\section{Relationship of epipelon variations to environmental conditions: statistical analyses}

Differences among the sites, tested through the oneway ANOVA using the community-descriptive variables, were statistically significant $(\mathrm{P}>0.05)$ in the case of species richness and chlorophyll-a concentration ( $\mathrm{P}=0.0001$ and 0.0034 , respectively). The Tukey post-hoc test indicated that, with the species richness differences were present between St. 4 and both St. 1 and St. 2 $(\mathrm{P}<0.001)$, and with the chlorophyll-a concentration were observed between St. 1 and both St. 3 and St. $4(\mathrm{P}<0.05)$.

Phase or regime differences were determined using four noncorrelated community-descriptive variables in an ANOSIM. The differences between the samples of the turbid and the clear-water phases, although significant (significance level: $0.01 \%$ ), were not marked, as the $R_{S}$ value was not high (0.31). Site and time differences in the densities of the most abundant species $(5 \%$ or more of the total density in any of the samples) were tested by the MDS ordination technique (Fig. 8). A tendency among the samples from the different sites to separate from each other was apparent, especially between St. 1 or St. 2 and those from St. 4. The separation between the turbid- and clear-water samples was not sharp, though still recognizable in the plot (Fig. 8, broken line). Although statistically significant, the overall site and phase differences were small when tested by ANOSIM (Global R statistic: 0.30 and R statistic, 0.34, respectively; significance level, $0.01 \%$ ). In contrast, some of the $\mathrm{R}$ values were higher with pairwise tests evaluating differences between the sites e.g., 0.52 (St. 1 vs St. 4), 0.42 (St. 2 vs St. 4), and 0.37 (St. $1 v s \mathrm{St}$. 3) -all with significance levels equal to $0.01 \%$.
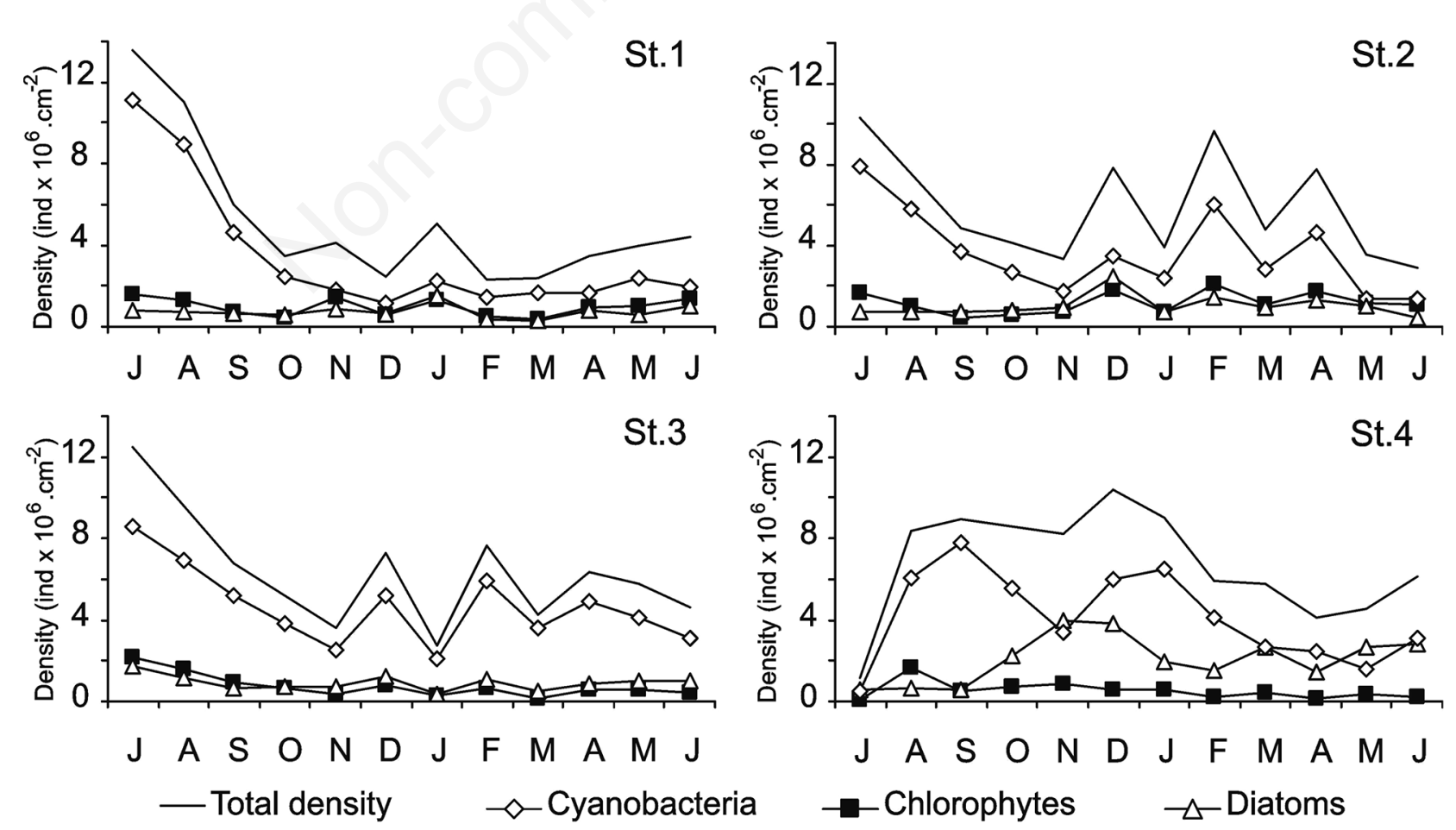

Fig. 3. Total density and density of the most abundant taxonomic groups at each station and on each sampling date. 
Significant Pearson's product-moment correlations were found among the descriptive-community and environmental variables that were related to the light climate underwater (Tab. 2). As regards sediment characteristics, the species richness correlated positively with the TP con- centrations and the density of the sediment; these latter two variables were related to differences among the four sites.

The relationships between environmental parameters (temperature, conductivity, turbidity, sediment-TP concentration, and sediment density) and the abundances of

Tab. 2. Product-moment Pearson's r-correlation coefficients.

\begin{tabular}{lccccc} 
& TDD & TB & Phaeo & \\
Water variables & & & & & \\
Temperature & -0.15 & -0.12 & $0.52^{*}$ & $0.32^{*}$ & -0.16 \\
Conductivity & $0.46^{*}$ & $0.35^{*}$ & $-0.56^{*}$ & 0.00 & -0.26 \\
Turbidity & $0.48^{*}$ & $0.41^{*}$ & $-0.61^{*}$ & -0.02 & -0.11 \\
Suspended solids & $0.33^{*}$ & $0.35^{*}$ & $-0.59^{*}$ & -0.16 & -0.28 \\
Phytoplanktic chlorophyll-a & $0.32^{*}$ & 0.22 & $-0.30^{*}$ & -0.01 & -0.15 \\
Phytoplanktic density & $0.43^{*}$ & $0.30^{*}$ & $-0.50^{*}$ & 0.20 & 0.07 \\
Reactive silica & 0.13 & 0.11 & $-0.38^{*}$ & -0.25 & $0.29 *$ \\
Nitrates and nitrites & 0.04 & 0.04 & 0.14 & -0.03 & 0.03 \\
Sediment variables & & & & $-0.30^{*}$ \\
Total phosphorus & -0.13 & 0.05 & -0.09 & 0.15 & $-0.54^{*}$ \\
Density & 0.04 & -0.08 & 0.15 & $0.47^{*}$ \\
\hline
\end{tabular}

$T D$, total density; TB, total biovolume; Phaeo, phaeopigments concentration; Chl-a, chlorophyll-a concentration; SR, species richness. Total number of observations, $n$ for each analysis $=48 .{ }^{*}$ Coefficients statistically significant at $P<0.05$.
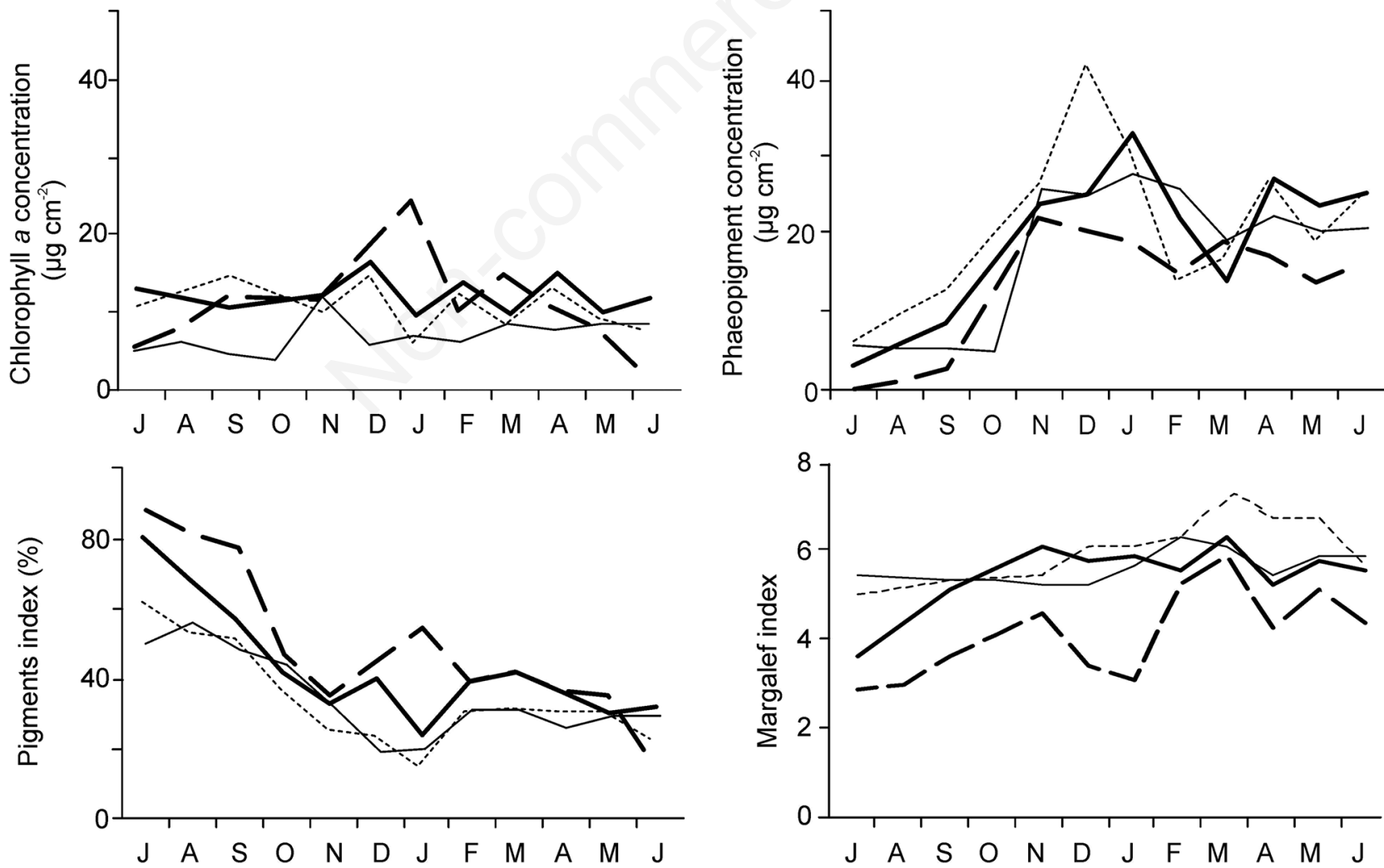

St. 1

St. 2

St. $3-\quad$ St. 4

Fig. 4. Epipelon pigment concentrations and pigment-related indices. 
the species were tested by BIO-ENV analysis. The highest $\mathrm{R}_{\mathrm{S}}(0.432)$ was obtained by the 4 -variable group of conductivity, turbidity, sediment-TP concentration, and sediment density. The combination of all the variables correlated at an $R_{S}=0.408$. All the environmental variables tested in combination explained only a small part of the species-abundance variations since the correlation coefficients were relatively moderate.

\section{DISCUSSION}

\section{Epipelon variations over space and time}

Although Lacombe is a shallow lake with a very smooth slope from the bank to the center, differences in epipelon structure with depth were nevertheless still present. Moreover, the assemblages at the shallower site (St. 4), being in a better physiologic state -as manifest in higher chlorophyll- $a$ values and lower Margalef's index- reflected the more suitable environmental conditions of the habitats nearer the shore (e.g., greater light availability and less accumulation of organic material on top of the algae). At the deeper sites, the epipelic density was higher during the winter and decreased during the spring. These variations were not related to a corresponding pattern with respect to chlorophyll- $a$ concentrations, a disparity that had also been found by Aberle and Wiltshire (2006). In contrast, at the shallower site St. 4, both these variables exhibited a seasonally changing pattern characterized by an initial increase in late winter and a second peak during the summer.

The relationship between the lake's regimes and the variations in the epipelic algae resulted in only a marginal separation between the samples from the turbid- and clear-water phases, probably stemming from the contributions coming from various other algal communities. Cano et al. (2008; 2012; 2013) and Casco et al. (2009) demonstrated that the abundances of phytoplankton and epiphyton followed the phase change in Lacombe Lake closely. Many algae in those assemblages can migrate or sediment to the lake bottom (Poulíčková et al., 2008), thus superimposing the variation patterns of their original communities onto the epipelon's own dynamics. Examples of these interchanges between communities were $P$. minor and $O$. parva (during the turbid phase these species were dominant among the phytoplankton; Casco et al., 2009).

\section{Epipelic algae and environmental variables}

Bourne (2000) found that environmental variables explained in part the variations in the epipelic-algal biomass. Likewise, epipelon variations in Lacombe Lake can also be explained by a complex combination of those diverse variables and not by one or two alone ( $c f$. the Pearson-r correlations and the BIO-ENV test). The hydrometric level and the light variations as a result of phytoplankton growth are closely interrelated, and this relationship de- pends on the rapidity at which the water level changes. A gradual increment may give time for the phytoplankton to grow back and counteract the effects of dilution. Under such conditions, light is intercepted by the planktic algae so that the epipelic algae become overshadowed (Hansson, 1992; Vadeboncoeur et al., 2002; Flödder et al., 2006). In Lacombe, the epipelon at the deeper stations (Sts. 1-3) may have experienced this resultant overshadowing after August precipitations. The October rainfalls were linked to the development of submerged macrophytes, a substantial diminution in the phytoplankton biomass and an increase in the percentages of incident light at the sediment surface. The improvement in light conditions was only evidenced at St. 4 where it may have favored the elevation in diatom density recorded. In spite of these more propitious conditions, an increase in phaeopigment concentrations was also registered at all stations by October or November. This increment indi-
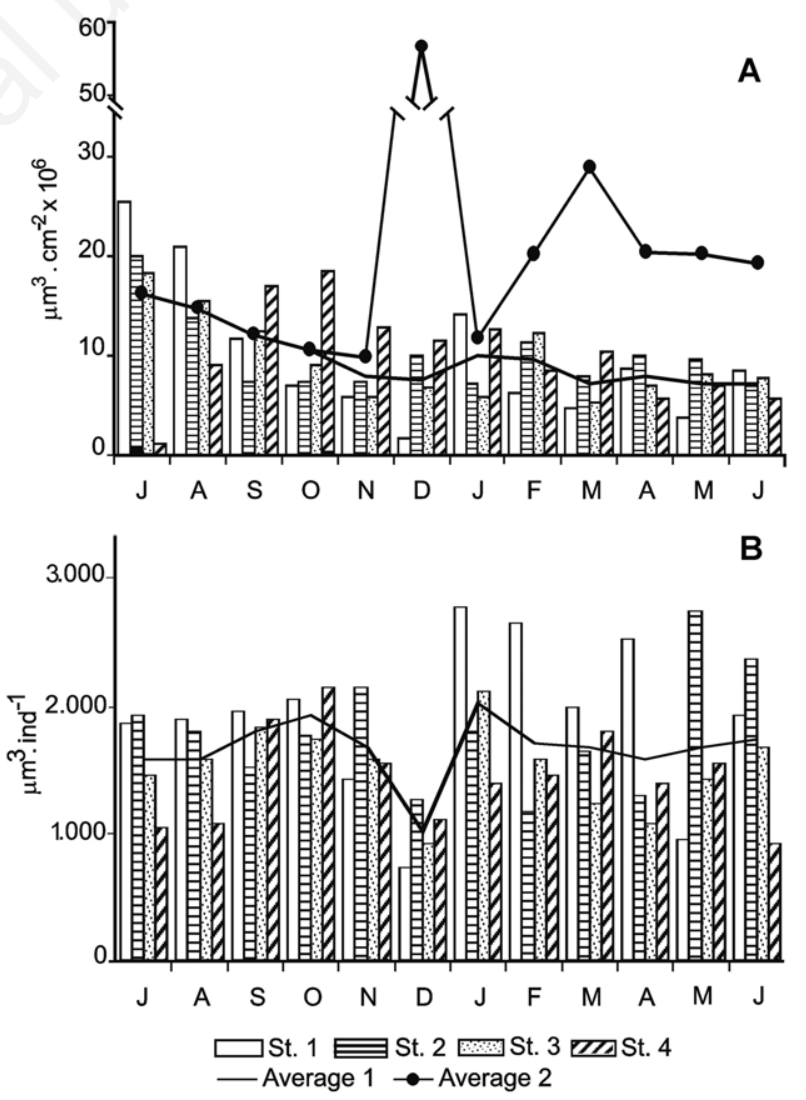

Fig. 5. Total biovolume (A) and biovolume per individual (B). Bars: values corresponding to each site and month. Average 1: average values of the four sites for each month not including the biovolumes of Microcystis aeruginosa. Average 2: average values of the four sites for each month including the biovolumes of $M$. aeruginosa. 
cated that the physiologic state of the organisms was not optimum, a condition that may have also be linked to the contribution of decaying organisms from the phytoplankton. Submerged macrophytes improve the water clarity by increasing the sedimentation rate of the suspended particles, by preventing sediment resuspension (Barko and James, 1998), and/or by providing refuge for the grazing zooplankton (Burks et al., 2001). All these effects may have been operative in Lacombe from October onwards and could have favored epipelon development. Nonetheless, submerged macrophytes can hamper epipelon development by shading the sediment surface when the cover becomes appreciable (Sand-Jensen and Borum, 1991; Lassen et al., 1997; Aberle and Wiltshire, 2006). This double-edged effect could have been operating at St. 4, where the increase in chlorophyll- $a$ concentration and diatom density were related to better light conditions. Both variables diminished in February, when submerged macrophytes attained higher percent coverages (ca. 100\%), but then they increased again when the plant coverage fell to $8 \%$ after the March rainfalls (Casco et al., 2009).

Since the availability of nutrients is usually greater in the sediments than in the water column, nutrient limitation in the epipelon is rather infrequent (Sand-Jensen and Borum, 1991). In Lacombe, we obtained no strongly significant correlations between the sediment-TP or -POM content and the epipelon variables. Phosphorus may have been more greatly associated with the decaying organic matter than with the living epipelic algae. The pool of nutrients in the water column plus the sediments would appear sufficient to cover the epipelon requirements.

Scour is one of the most common physical perturba-
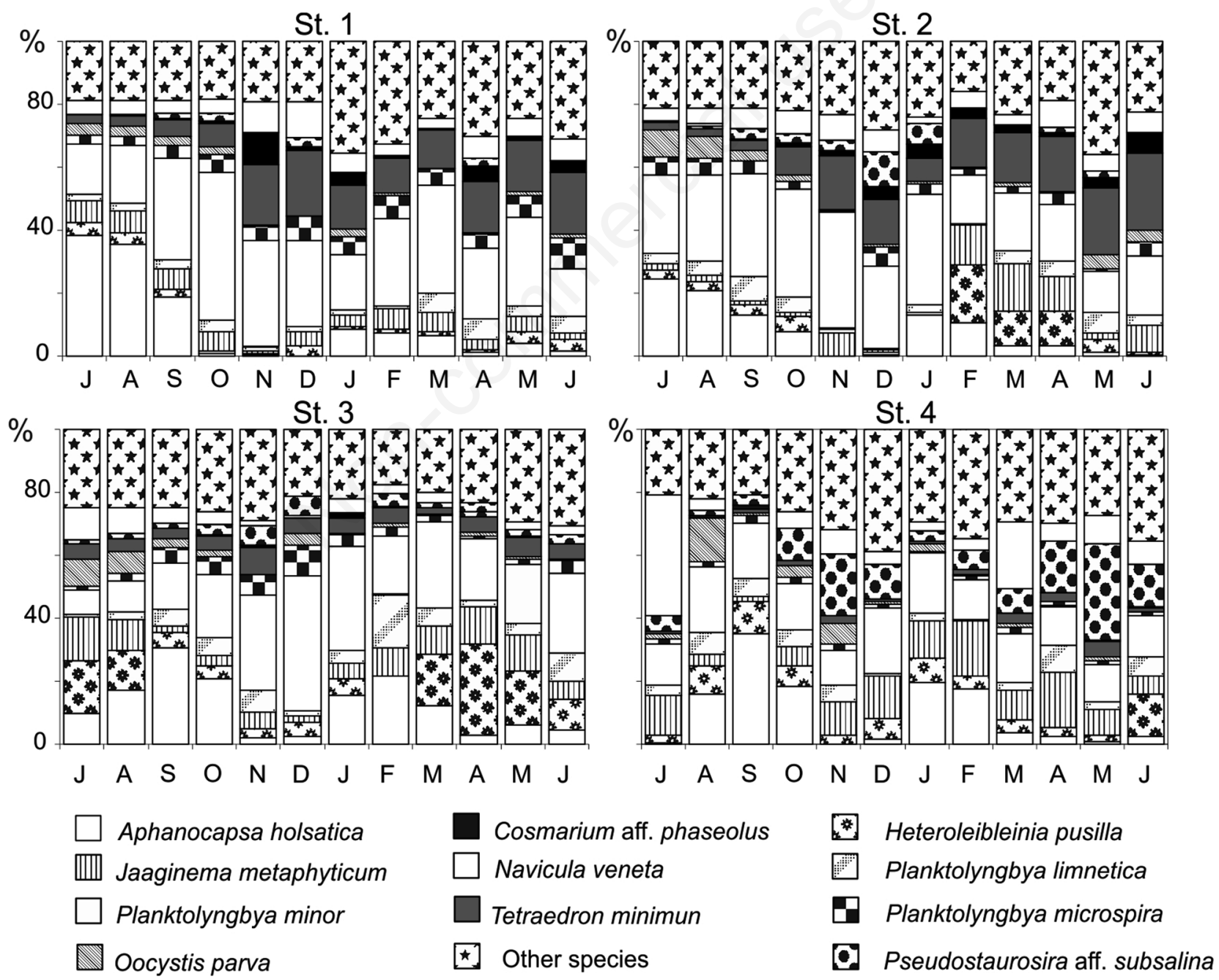

Fig. 6. Percent contributions of the most abundant species to the total density at the four stations on all sampling dates. The species represented contributed $10 \%$ or more to the total density in any of the samples. 
tions to which the epipelic algae are subjected (Peterson, 1996). In Lacombe, less dense sediments with high concentrations of POM and TP were found at the deeper sites St. 1 and St. 2. These characteristics are typical of sites with high rates of sediment accretion (Barko and James, 1998). At these stations the presence of submerged or emergent plants and/or the water column depth may prevent the resuspension of sediment and increase the sedimentation rate of the suspended particles by contributing to water-column stabilization (Barko and James, 1998; Horppila and Nurminen, 2001). In contrast, at St. 4, the sediments were exposed to more intense water movements at the shore zone, thus the sediment density was higher (higher content of sand grains and lower POM levels). As reported by Barko and James (1998), this pattern occurs within an erosional environment. The relative balance between accretion and erosion among the different sites was likewise reflected in discrepancies in the diatom-size classes. The largest diatoms, C. clypeus and S. striatula, predominated in most of the samples of accretional sites, St. 1 and St. 2. By contrast, smaller di- atoms (e.g., $N$. veneta, $N$. amphibia, $H$. veneta, and $R$. gibba, among others) predominated at the erosional site, St. 4. The details of a diatom's shape may entail specific advantages or disadvantages for any particular site. In the loose organic sediments organisms must have a way to counteract the tendency to sink through that flabby, easily permeated matrix (Round and Eaton, 1966). Larger flat cells, as $C$. clypeus and $S$. striatula, have a more extended surface apposing the sediments and thus may become buried more slowly. In contrast, at sites where sand grains are abundant, small needle-like or lanceolate diatoms may easily occupy depressions and spaces between particles thereby avoiding the water movements that could wash those diatoms away. Except for the very small cyanobacteria species Xenococcus minimus and Heteroleibleinia pusilla, the rest of the taxa found at St. 4 were not attached to the sand grains; therefore, wave action must have been a form of disturbance requiring confrontation. Although these observations were made in a shallow lake, the details are coincident with what Cantonati and Lowe (2014) pointed out for
St. 1

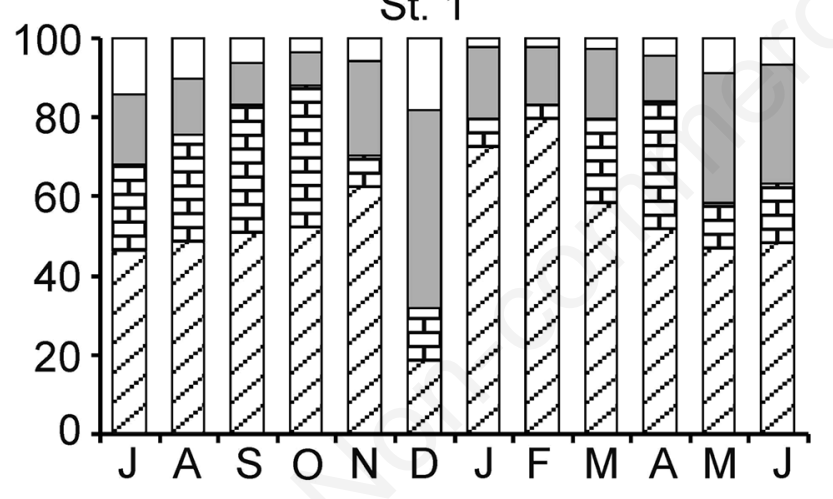

St. 3

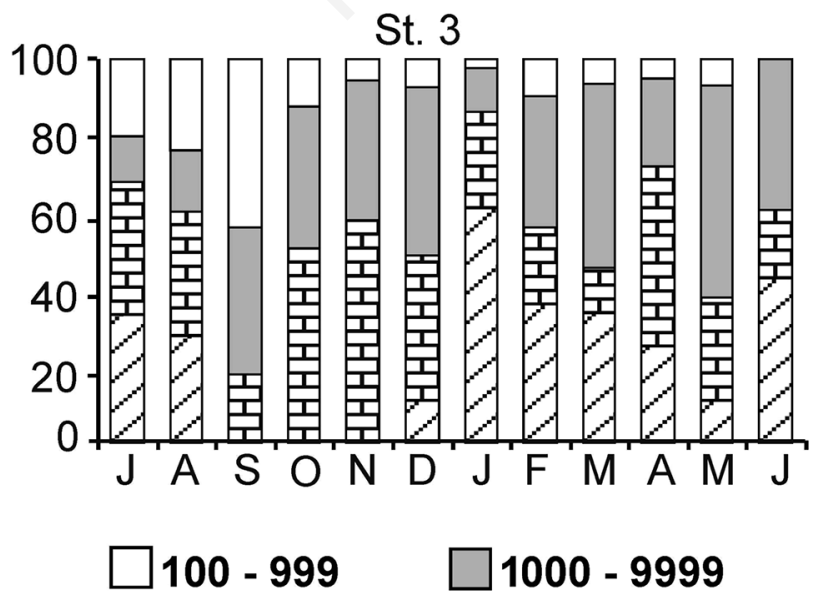

St. 2

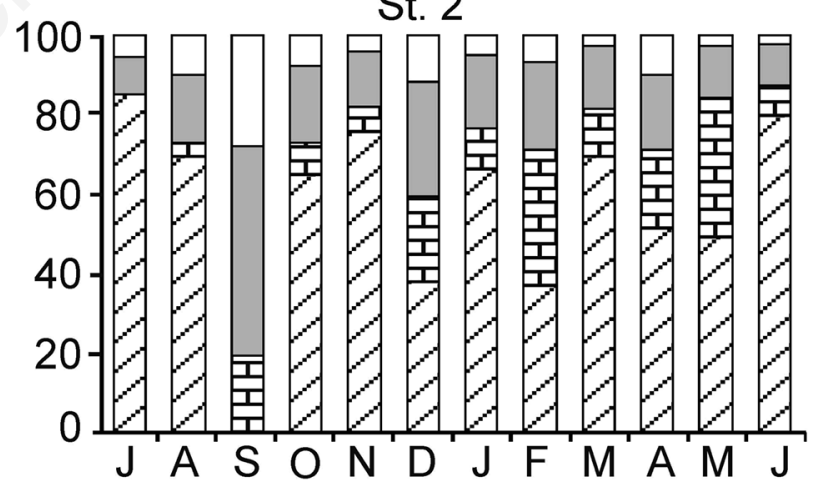

St. 4

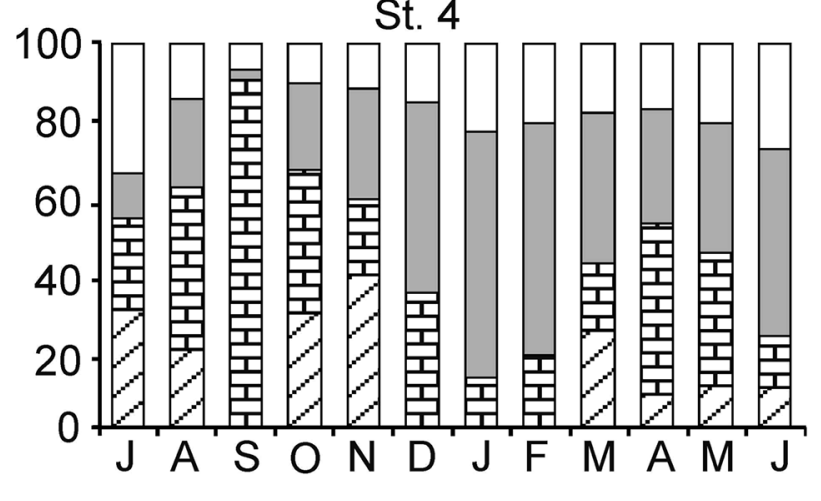

四10,000 - 99,999

Fig. 7. Contributions of diatom-biovolume classes to the total diatom biovolume at the four stations on all sampling dates. Size ranges in $\mu \mathrm{m}^{3}$. 
larger lakes. Those authors stated that in general, causes of disturbance are most influential in the shallow zones than in the more stable deeper zones and that these differences may influence the diatom assemblage composition.

\section{CONCLUSIONS}

The epipelon variations analyzed in this investigation exemplify the reference communities which are developed during clear or turbid regimes according to the model of Scheffer et al. (1993) in Pampean shallow lakes, particularly in those lacking inlets and outlets. Related to our main working hypothesis, our findings indicated that light conditions followed by substrate instability due to wave action appear to be the maindrivers of epipelon variations over space and time. On the contrary, as it is true in most eutrophic systems, no clues for nutrient deficiency could be obtained. We emphasize the closely relationships between the epipelon and other communities. The phytoplankton and the epiphyton may superimpose their own patterns of variation onto the epipelon dynamics thus transforming this community in a very complex and changing assemblage of organisms.

\section{ACKNOWLEDGMENTS}

This work was supported by Consejo Nacional de Investigaciones Científicas y Técnicas (CONICET) and Universidad Nacional de La Plata (UNLP) funds and fellowships. We want to thank Dra. M. E. MacDonagh, Dra. L. Solari, and Dr. M. Ardohain for their help during field and lab work. We are especially thankful to Dra. J. Toja (Universidad de Sevilla, España) for letting us use PRIMER 5.2.9 statistical package under her permission and are grateful to Dr. D.F. Haggerty, a retired academic career investigator and native English speaker, for editing the final version of the manuscript.

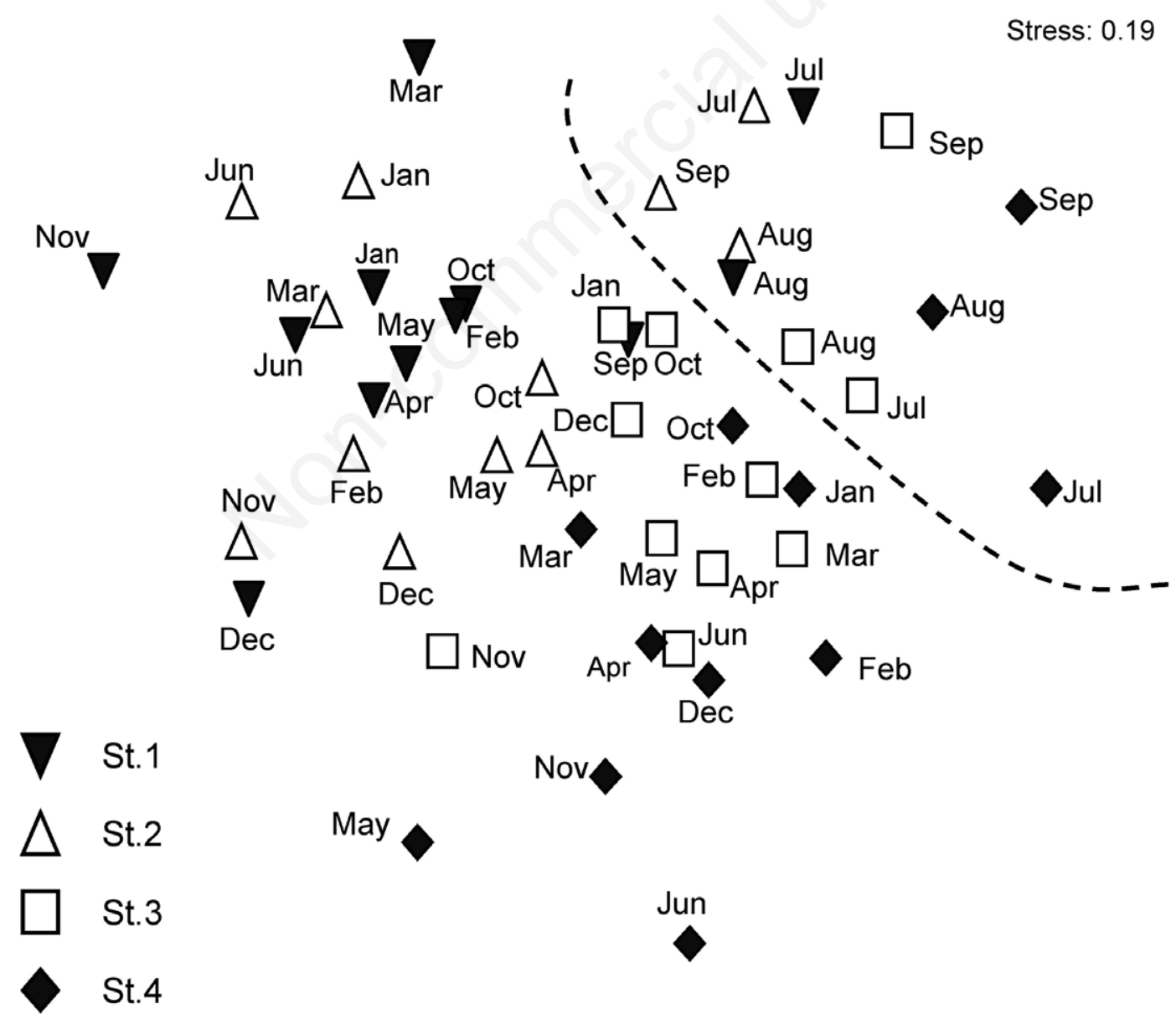

Fig. 8. Ordination plot of MDS analysis of species density. Species contributing 5\% or more to the total density in any of the samples were included. Broken line: separation between the turbid-water-phase samples (July-September period) and the clear-water-phase samples (October-June period). 


\section{REFERENCES}

Aberle N, Wiltshire KH, 2006. Seasonality and diversity patterns of microphytobenthos in a mesotrophic lake. Arch. Hydrobiol. 167:447-465.

Allende L, Tell G, Zagarese H, Torremorell A, Pérez G, Bustingorry J, Escaray R, Izaguirre I, 2009. Phytoplankton and primary production in clear-vegetated, inorganic-turbid, and algal-turbid shallow lakes from the pampa plain (Argentina). Hydrobiologia 624:45-60.

Ardohain DM, Benítez HH, Gabellone NA, Claps MC, 2014. [Respuesta de la estructura zooplanctónica a cambios físicos y biológicos en una laguna pampásica (laguna Lacombe)].[Article in Spanish]. Biología Acuática 30:17-26.

Barko JW, James WF, 1998. Chapter 10. Effects of submerged aquatic macrophytes on nutrient dynamics, sedimentation, and resuspension, p. 197-214. In: E. Jeppesen, Ma. Søndergaard, Mo. Søndergaard and K. Christofferson (eds.), The structuring role of submerged macrophytes in lakes. Springer.

Bennion H, Kelly MG, Juggins S, Yallop ML, Burgess A, Jamieson J, Krokowski J, 2014. Assessment of ecological status in UK lakes using benthic diatoms. Freshwater Sci. 33:639-654.

Bourne ALE, 2000. Factors influencing the abundance of sediment-associated algae in two isolated ponds and a turbid channel of Delta Marsh, Manitoba. MS Thesis, University of Manitoba, Canada.

Burks RL, Jeppesen E, Lodge DM, 2001. Littoral zone structures as Daphnia refugia against fish predators. Limnol. Oceanogr. 46:230-237.

Cano MG, 2009. [Fitoperifiton de un lago somero y su relación con los estados de biequilibrio].[PhD thesis in Spanish]. Universidad Nacional de La Plata, Argentina.

Cano M, Casco M, Claps M, 2012. Effect of environmental variables on epiphyton in a Pampean lake with stable turbid-and clear-water states. Aquat. Biol. 15:47-59.

Cano M, Casco M, Claps M, 2013. Vertical distribution of epiphyton biomass and diversity in a shallow lake during contrasting ecosystem regimes. Aquat. Bot. 110:38-47.

Cano MG, Casco MA, Solari LC, Mac Donagh ME, Claps MC, 2008. Implications of rapid changes in chlorophyll-a of plankton, epipelon, and epiphyton in a Pampean shallow lake: an interpretation in terms of a conceptual model. Hydrobiologia 614:33-45.

Cantonati M, Lowe RL, 2014. Lake benthic algae: toward an understanding of their ecology. Freshwater Sci. 33:475-486.

Casco MA, Mac Donagh ME, Cano MG, Solari L, Claps MC, Gabellone N, 2009. Phytoplankton and epipelon responses to clear and turbid phases in a seepage lake (Buenos Aires, Argentina). Int. Rev. Hydrobiol. 94:153-168.

Cattaneo A, 1983. Grazing on epiphytes. Hydrobiologia 23:124132.

Clarke KR, Warwick RM, 2001. Change in marine communities: an approach to statistical analysis and interpretation, 2nd edition. Plymouth Marine Laboratory, UK: $176 \mathrm{pp}$.

Dodds WK, 2003. The role of periphyton in phosphorus retention in shallow freshwater aquatic systems. J. Phycol. 39:840-849.

Flödder S, Combüchen A, Pasternak A, Hillebrand H, 2006.
Competition between pelagic and benthic microalgae for phosphorus and light. Aquat. Sci. 68:425-433.

Goldsborough LG, Robinson GGC, 1996. Patterns in wetlands, p. 77-117. In: R.J. Stevenson, M.L. Bothwell and R.L. Lowe (eds.), Algal ecology: freshwater benthic ecosystems. Academic Press, San Diego.

Gómez SE, Toresani NI, 1999. [Región 3. Pampas, p. 97-113]. In: P. Canevari, D. Blanco, E. Bucher, G. Castro and I. Davison (eds.), [Los humedales de la Argentina: Clasificación, situación actual, conservación y legislación].[Book in Spanish]. Wetlands Int., Publication 46. Buenos Aires.

Guiry MD, Guiry GM, 2015. AlgaeBase. World-wide electronic publication, National University of Ireland, Galway. Available from: http://www.algaebase.org

Hansson LA, 1988. Effects of competitive interactions on the biomass development of planktonic and periphytic algae in lakes. Limnol. Oceanogr. 33:121-128.

Hansson LA, 1992. Factors regulating algal biomass. Limnol. Oceanogr. 37:322-332.

Hillebrand H, Dürselen CD, Kirschtel D, Pollingher U, 1999. Biovolume calculation for pelagic and benthic microalgae. J. Phycol. 35:403-424.

Horppila J, Nurminen L, 2001. The effect of an emergent macrophyte (Typha angustifolia) on sediment resuspension in a shallow north temperate lake. Freshwater Biol. 46:1447-1455.

Izaguirre I, Vinocur A, 1994. Typology of shallow lakes of the Salado River basin (Argentina), based on phytoplankton communities. Hydrobiologia 277:49-62.

Jansson M, 1980. Role of benthic algae in transport of nitrogen from sediment to lake water in a shallow clearwater lake. Arch. Hydrobiol. 89:101-109.

Lassen C, Revsbech NP, Pedersen O, 1997. Macrophyte development and resuspension regulate the photosynthesis and production of benthic microalgae. Hydrobiologia 350:1-11.

Libouriussen L, Jeppesen E, 2006. Structure, biomass, production and depth distribution of periphyton on artificial substratum in shallow lakes with contrasting nutrient con concentrations. Freshwater Biol. 51:95-109.

Margalef R, 1974. [Ecología].[Book in Spanish]. Ed. Omega, Barcelona: $1010 \mathrm{pp}$.

Moss B, 1977. Adaptations of epipelic and epipsammic freshwater algae. Oecologia 28:103-108.

Peterson CG, 1996. Response of benthic algal communities to natural physical disturbance, p. 375-402. In: R.J. Stevenson, M.L. Bothwell and R.L. Lowe (eds.), Algal ecology: freshwater benthic ecosystems. Academic Press.

Poulíčková A, Dvořák P, Mazalová P, Hašler P, 2014. Epipelic microphototrophs: an overlooked assemblage in lake ecosystems. Freshwater Sci. 33:513-523.

Poulíčková A, Hašler P, Lysáková M, Spears B, 2008. The ecology of freshwater epipelic algae: an update. Phycologia 47:437-450.

Quirós R, Rennella AM, Boveri MB, Rosso JJ, Sosnovsky A, 2002. [Factores que afectan la estructura y el funcionamiento de las lagunas Pampeanas].[Article in Spanish]. Ecol. Austral. 12:175-185.

Ramírez B, 2005. [Distribución vertical de clorofila en los fiordos australes ubicados entre el estrecho de Magallanes y el Cabo de Hornos (Chile) ].[Article in Spanish]. Cienc. Tecnol. Mar. 28:43-61. 
Rautio M, Vincent WF, 2006. Benthic and pelagic food resources for zooplankton in shallow high-latitude lakes and ponds. Freshwater Biol. 51:1038-1052.

Round, FE, Eaton JW, 1966. Persistent, vertical-migration rhythms in benthic microflora. III. The rhythm of epipelic algae in a freshwater pond. J. Ecol. 54:609-615.

Rott E, 1981. Some results from phytoplankton counting intercalibrations. Schweiz. Z. Hydrol. 43:34-62.

Sand-Jensen K, Borum J, 1991. Interactions among phytoplankton, periphyton, and macrophytes in temperate freshwaters and estuaries. Aquat. Bot. 41:137-175.

Scheffer M, 1998. Ecology of Shallow Lakes. London, UK,Chapman \& Hall Series. 357p.

Scheffer M, Hosper SH, Meijer ML, Moss B, Jeppesen E, 1993. Alternative equilibria in shallow lakes. Trends Ecol. Evol. 8:275-279.

Stevenson RJ, 1996. An introduction to algal ecology in freshwater benthic habitats, p. 3-30. In: R.J. Stevenson, M.L.
Bothwell and R.L. Lowe (eds.), Algal ecology: freshwater benthic ecosystems. Academic Press.

Strayer D, Likens GE, 1986. An energy budget for the zoobenthos of Mirror Lake, New Hampshire. Ecology 67:303-313.

Tur NM, Rossi JB, 1976. Autoecología de Scirpus californicus. 1. Crecimiento y desarrollo de la parte aérea. Bol. Soc. Arg. Bot. 17:3-82.

Vadeboncoeur Y, Lodge DM, Carpenter SR, 2001. Whole lake fertilization effects on distribution of primary production between benthic and pelagic habitats. Ecology 82:10651077.

Vadeboncoeur Y, Vander Zanden MJ, Lodge DM, 2002. Putting the lake back together: reintegrating benthic pathways into lake food web models. BioScience 52:44-54.

Wilmotte A, Goffart A, Demoulin V, 1988. Studies of marine epiphytic algae, Calvi, Corsica. I. Determination of minimal sampling areas for microscopic algal epiphytes. Brit. Phycol. J. 23:251-258. 